\title{
Observations on the epidemiology of club foot in Polynesian and Caucasian populations
}

\author{
IAN CARTLIDGE \\ From the Orthopaedic Department, Royal Hospital for Sick Children, Yorkhill, Glasgow G3 8.SJ.
}

SUMmary Although Polynesians are affected by idiopathic club foot deformity more commor than other racial groups, epidemiological surveys performed in Auckland and Glasgow showed other significant difference in their pattern of presentation compared with Caucasians. Distinctio in sex ratio and maternal age, reported previously between groups of index cases with and withou family history of the condition, were not confirmed in either racial group, and the predominance right sided over left sided unilateral cases was no greater in Polynesians than in Caucasians. The was an excess of sporadic cases born to very young mothers among the Maori population.

Racial differences in the incidence of idiopathic congenital talipes equinovarus (club foot) have been reported by several authors, ${ }^{1-4}$ the lowest incidence being among the Chinese with $0 \cdot 39 / 1000$ live births. Caucasian populations yield 1 to 2 cases of club foot deformity per 1000 , while the highest incidence is found in the Polynesian peoples of the South Pacific with $6 \cdot 5$ to $7 / 1000$ live births. ${ }^{4}$

Polynesia is a vast triangular area with points at Hawaii, Easter Island, and New Zealand. Over the centuries the "land of the long white cloud" in its south-western corner has attracted sea-borne peoples from other islands, the Maori influx being dated around 600 years ago. Indigenous Maoris, together with more recent immigrants from the Pacific Islands, now constitute some $10 \%$ of the New Zealand population, and approximately $16 \%$ of the population (c 800000 ) of Auckland in the North Island, the country's largest city, and the greatest concentration of Polynesians in the world (Provisional Census Figures, Department of Statistics, New Zealand Government, 1981). The Maoris constitute $8.3 \%$ and the Pacific Islanders $7.6 \%$ of the population of Auckland.

While a tradition exists of treating club feet by regular grandmaternal massage and manipulation, ${ }^{6}$ the Polynesians who have settled in Auckland embrace European methods of management, and attend the talipes clinics in sufficient numbers to provide opportunity and stimulus for study.

An epidemiological survey has been carried out and observations made on some similarities and differences between Polynesian and Caucasian club

Received for publication 14 October 1983.

Accepted for publication 9 December 1983. feet. One purpose has been to test the hypothesis Palmer, ${ }^{7}$ still sometimes quoted, that index patier with the condition settle into two groups dependi upon the existence or otherwise of affected relativi Palmer found, among Caucasians, that the larg group with a negative family history included $t \mathrm{~s}$ males for every female and had mothers young than average, while those in the smaller group wi affected relatives divided approximately equally in male and female and had mothers of average age.

\section{Materials and methods}

During 1982, studies were undertaken of 1 Polynesian children at Middlemore Hospit: Auckland, and then 120 Caucasian children at t Royal Hospital for Sick Children, Glasgow, wl were treated for idiopathic club foot deformity, $f$ whom a family history could be obtained, and t] maternal age at the time of their birth ascertaine Club feet secondary to neurological disorder myopathy, such as myelodysplasia or arthrogrypos were excluded from the studies.

Full pedigrees were not obtained, but a recos was made of the first and second degree affects relatives of each child with a positive family histor together with any more distant affected relative Note was also taken of the child's sex, the side । sides affected by club foot, its severity, and tl management, whether conservative or operative.

Among the Polynesians, Maori racial backgrour was accepted for children whose parents were bo Maori or part-Maori, and Pacific Island Polynesic background for children whose parents claimed pa or full origin in a stated island. The ages of $4 C$ 
Polynesian mothers producing consecutive live births at the Middlemore Maternity Unit were ascertained for comparison with the study group in Auckland, and average maternal ages in the Queen Mother's Hospital and Royal Maternity Hospital, Glasgow, and in all Scotland, obtained for comparison with the Glasgow study group (Information Services Division, Scottish Health Service Common Services Agency, Edinburgh).

\section{Results}

SEX / LATERALITY

In both racial groups the male:female ratio was $2 \cdot 2: 1$ and bilateral club feet were marginally less common than unilateral (table 1). Cases involving only the right foot predominated over left sided cases by $32 \%$ to $27 \%$ among Polynesians and by $29 \%$ to $22 \%$ among Caucasians.

\section{FAMILY HISTORY}

A positive family history of idiopathic club foot deformity was obtained for $64(54 \%)$ of the Polynesian children, and for $36(30 \%)$ of the Caucasians (table 2). Maori parentage was claimed for 50 of the 64 in the former group. Thirteen of these Maori cases were sibs in four distinct families. No known interrelationship existed between the remaining Maori children or between any of the Pacific Island cases. There were nine affected sibs among the group of Caucasian children with club feet, compared with 168 sibs who were unaffected. No sets of twins were found. Table 3 shows the closest affected relative of each child with a positive family history. Twenty-six additional relatives were affected in the Polynesian group and 17 in the Caucasian.

TABLE 1 Details of patients: sex and laterality.

\begin{tabular}{lll}
\hline Sex/laterality & Polynesian (Auckland) & Caucasian (Glasgow) \\
\hline Number & 118 & 120 \\
M:F & $81: 37(2 \cdot 2: 1)$ & $82: 38(2 \cdot 2: 1)$ \\
Bilateral & $48(41 \%)$ & $59(49 \%)$ \\
Unilateral (R:L) & $70(38: 32=32 \%: 27 \%)$ & $61(35: 26=29 \%: 22 \%)$ \\
\hline
\end{tabular}

MATERNAL AGE

No difference in sex ratio and no significant difference in mean maternal age existed between those with and those without a family history of club foot in either racial group (table 4). However, mothers of children with a negative family history, who were under the age of 18 at their birth, outnumbered their equivalent in the group with a positive family history by $8: 1$ among Polynesians and 2:0 among Caucasians.

\section{GIRLS}

Among female cases, bilateral club foot predominated over unilateral in Caucasian girls with affected relatives (table 4), but in Polynesians unilateral cases were more numerous, independent of family history.

\section{SEVERITY}

No correlation was found between the presence or absence of a family history of idiopathic club foot and the severity of the condition. Bilateral cases, however, were more severe than unilateral, particularly in Caucasian children (table 5) in whom regular manipulation and splintage of single involved feet, especially on the left side, gained satisfactory correction in more than $30 \%$ of cases without recourse to soft tissue release procedures. These were generally delayed in Glasgow until the child was

TABLE 3 Closest affected relatives in patients with a positive family history.

\begin{tabular}{lll}
\hline Closest affected relative & $\begin{array}{l}\text { Polynesian } \\
(n=64)\end{array}$ & $\begin{array}{l}\text { Caucasian } \\
(n=36)\end{array}$ \\
\hline 1st degree (parent/sib) & 26 & 15 \\
2nd degree (aunt/uncle/grandparent) & 21 & 5 \\
3rd degree (<25\% genetic resemblance) & 17 & 16 \\
\hline
\end{tabular}

TABLE 4 Details of female patients.

\begin{tabular}{lll}
\hline Females & Polynesian $(n-37)$ & Causasian $(n=38)$ \\
\hline $\begin{array}{l}\text { Positive family history } \\
\text { (bilateral :unilateral) }\end{array}$ & $20(9: 11=45 \%: 55 \%)$ & $11(7: 4=63 \%: 37 \%)$ \\
$\begin{array}{c}\text { Negative family history } 17(8: 9-47 \%: 53 \%) \\
\text { (bilateral :unilateral) }\end{array}$ & $27(12: 15=44 \%: 56 \%)$ \\
\hline
\end{tabular}

TABLE 2 Family history: sex and maternal age.

\begin{tabular}{|c|c|c|c|}
\hline \multirow[t]{2}{*}{ Family history } & \multicolumn{2}{|l|}{ Polynesian $(n=118)$} & \multirow[t]{2}{*}{ Caucasian $(n=120)$} \\
\hline & Maori $(n-76)$ & Pacific Island $(n=42)$ & \\
\hline \multicolumn{4}{|l|}{ Positive } \\
\hline No & $50(66 \%)$ & $14(33 \%)$ & $36(30 \%)$ \\
\hline$M: F$ & $34: 16$ & $10: 4$ & $25: 11$ \\
\hline Maternal age range:mean & $17-38: 24 \cdot 1$ years & $18-30: 24 \cdot 6$ years & $18-34: 26 \cdot 3$ years \\
\hline \multicolumn{4}{|l|}{ Negative } \\
\hline No & $26(34 \%)$ & $28(67 \%)$ & $84(70 \%)$ \\
\hline $\mathrm{M}: \mathrm{F}$ & $18: 8$ & $19: 9$ & $57: 27$ \\
\hline Maternal age range:mean & $15-32: 22 \cdot 9$ years & $15-45: 24 \cdot 7$ years & $16-42: 26 \cdot 9$ years \\
\hline
\end{tabular}

Mean maternal ages in controls: Polynesian $24 \cdot 1$ years.

Caucasian $25 \cdot 8$ years. 
TABLE 5 Severity of affected feet compared with laterality.

\begin{tabular}{|c|c|c|c|c|c|c|}
\hline \multirow[t]{2}{*}{ Severity } & \multicolumn{3}{|l|}{ Polynesian } & \multicolumn{3}{|l|}{ Caucasian } \\
\hline & Bilateral $n=48$ & Rt only $n=38$ & Lt only $n=32$ & Bilateral $n=59$ & Rt only $n=35$ & Lt only $n=26$ \\
\hline $\begin{array}{l}\text { Mild } \\
\text { Severe }\end{array}$ & $\begin{array}{r}51 *(11 \%) \\
42 \frac{1}{2} *(89 \%)\end{array}$ & $\begin{array}{r}7(18 \%) \\
31(82 \%)\end{array}$ & $\begin{array}{r}5(16 \%) \\
27(84 \%)\end{array}$ & $\begin{array}{r}9 \frac{5}{2} \dagger(20 \%) \\
45^{5} \dagger(80 \%)\end{array}$ & $\begin{array}{l}11(31 \%) \\
24(69 \%)\end{array}$ & $\begin{array}{l}12(46 \%) \\
14(54 \%)\end{array}$ \\
\hline
\end{tabular}

*In one case only the left foot required operative release.

tOperative release required in one left and four right feet, where the opposite foot responded to conservative treatment.

weightbearing in the second year of life. A disposition to earlier operative intervention in Auckland, at around the 3 month stage, correlates with the higher percentage of feet deemed sufficiently severe to require surgical release.

\section{Discussion}

Genetic predisposition to idiopathic club foot deformity involves a pattern of inheritance which is polygenic and multifactorial. ${ }^{89} \mathrm{~A}$ higher frequency of the important genes in Polynesian populations is thought to explain the high incidence of club foot in the South Pacific peoples, together with higher recurrence risks than those quoted for Caucasian index cases. ${ }^{5}$

Intrauterine environmental factors, acting during the critical sixth to eighth week of fetal life, have also been implicated in the causation of club foot, ${ }^{10}$ and the influence of the young primigravid uterus was suggested by Palmer's finding ${ }^{7}$ of younger mothers in a group of affected Caucasian children with a negative family history of club foot.

Some support for this contention is provided by the overall 10:1 predominance of mothers under the age of 18 years in the 'negative' group, but in this study the Caucasian group with no affected relatives had mothers whose mean age (26.9 years) was comparable with normal controls, and, although equivalent mothers in the Maori subgroup of Polynesians had a mean age of 22.9 years, this does not differ significantly from the control value of $24 \cdot 1$ years for Polynesians. Furthermore, whereas the cases with an affected relative in Palmer's study ${ }^{7}$ were equally male and female, the Polynesian and Caucasian groups described here had the expected male:female ratio of more than $2: 1$, independent of family history.

It is noteworthy that a discrepancy exists between the Maori Polynesian sub-group in which those with an affected relative predominated by $50: 26$, and the corresponding sub-group with origin in the Pacific Islands, which was smaller by 14:28. Known interrelationship among 13 of the Maori cases explains part of the discrepancy, but it would seem also that the genes predisposing to club foot may be more prevalent in the Maori community of Auckland than in the incomers from the Pacific Islands.

Approximately equal numbers of bilateral and unilateral cases and, among the latter, a slight predominance of right sided feet, concurs with previous reports ${ }^{4} 70$ of Caucasian club foot, as does the greater severity of bilateral cases. The data of Beals ${ }^{5}$ and of Chung and Nemechek ${ }^{4}$ for Polynesians suggest a 2:1 predominance of right over left feet in unilateral cases, but the ratio in this study $(38: 32)$ does not support the racial difference in laterality.

Polynesian girls, however, did differ from their Caucasian counterparts with a positive family history. Palmer, ${ }^{7}$ Wynne Davies, ${ }^{8}$ and Turco ${ }^{10}$ found that bilateral cases were more numerous than unilateral in this group, and the Caucasian girls reported here seemed to follow that pattern. No such predominance of bilateral cases was seen among female Polynesians with affected relatives.

\section{References}

1 Wynne-Davies R. Heritable disorders in orthopaedic practice. Oxford: Blackwell Scientific Publications, 1973.

2 Stewart SF. Club foot: its incidence, cause and treatment. $J$ Bone Joint Surg $[\mathrm{Am}] 1951 ; 33: 577-88$.

3 Ching CHS, Chung CS, Nemechek RW. Genetic and epidemiological studies of club foot in Hawaii: ascertainment and incidence. Am J Hum Genet 1969;21:556-80.

${ }^{4}$ Chung CS, Nemechek RW, Larsen IJ, Ching CHS. Genetic and epidemiological studies of club foot in Hawaii. Hum Hered 1969;19:321-42.

5 Beals RK. Club foot in the Maori: a genetic study of 50 kindreds. NZ Med J 1978;88:144-6.

6 Phillips WJ. Maori life and custnms. Wellington: Reed, 1966.

7 Palmer RM. The genetics of talipes equinovarus. $J$ Bone Joint Surg [Am] 1964;46:542-56.

8 Wynne-Davies R. Family studies of congenital club foot. J Bone Joint Surg [Br] 1964;46:445-63.

9 Cowell HR, Wein BK. Current concepts review-genetic aspects of club foot. J Bone Joint Surg [Am] 1980;62: $1381-4$.

10 Turco VJ. Club foot. New York: Churchill Livingstone, 1981.

Correspondence and requests for reprints to $\mathrm{Mr}$ I Cartlidge, FRCS, Orthopaedic Department, Royal Hospital for Sick Children, Yorkhill, Glasgow G3 8SJ. 